$\begin{array}{r}\text { Phinisi Integration Review } \\ \text { Vol. 1, No.2, Agustus 2018 Hal 133-140 } \\ \text { Website: http:///ojs.unm.ac.id/pir } \\ \text { p-ISSN: 2614-2325 dan e-ISSN: 2614-2317 } \\ \hline\end{array}$

\title{
Pengaruh Kecerdasan Emosional Siswa Dan Partisipasi Orang Tua Terhadap Hasil Belajar Siswa SMPN 1 Marioriwawo Kabupaten Soppeng
}

\author{
Megawati \\ Program Pascasarjana, Universitas Negeri Makassar \\ Email: Megawati.masse@gmail.com
}

\begin{abstract}
Abstrak. Tujuan penelitian adalah untuk mengetahui (i) pengaruh kecerdasan emosional siswa terhadap hasil belajar siswa mata pelajaran IPS; (ii pengaruh partisipasi orang tua terhadap hasil belajar siswa mata pelajaran IPS (iii) pengaruh kecerdasan emosional siswa dan partisipasi orang tua secara simultan terhadap hasil belajar siswa mata pelajaran IPS. Jenis penelitian ini adalah penelitian kuantitatif. Populasi dalam penelitian ini adalah seluruh siswa kelas VIII SMP Negeri 1 Marioriwawo. Teknik pengambilan sampel dengan Cluster random sampling, sebanyak 90 siswa. Teknik Analisi Data menggunakan Analisis Statistik Deskriptif dan Analisis Statistik Inferensial. Hasil penelitian menunjukkan bahwa pertama, Pengaruh kecerdasan emosional siswa terhadap hasil belajar siswa mata pelajaran IPS memiliki pengaruh signifikan. Kedua, Pengaruh partisipasi orang tua terhadap hasil belajar siswa mata pelajaran IPS memiliki pengaruh signifikan. Ketiga, hasil uji simultan menunjukkan bahwa kecerdasan emosional siswa dan partisipasi orang tua memiliki pengaruh yang signifikan terhadap hasil belajar.
\end{abstract}

Kata kunci : kecerdasan emosional siswa, partisipasi orang tua, hasil belajar siswa.

Abstract. In this research there are three problem formulation is (i) whether there is emotional intelligence of students on learning results in social sciences subject (ii) whether there is influence of parents' participation on learning results in social sciences, (iii) whether there is influence of students' emotional intelligence and parents' participation sumultaneously on learning results in social sciences subject in class VIII students at SMPN 1 Marioriwawo in Soppeng district. The type of this study is quantitative. In terms of its purpose, this research is a comparative causal research. The population of the study were all students of class VIII at SMPN I Marioriwawo. The sample selection technique employed cluster random sampling and obtained 90 students as the samples. Data were analyzed by employing descriptive statistics analysis and inferential statistics analysis. The results of tge study reveal that: first, the students' intelligence gives significant influence on learning results in soscial sciences subject in class VIII students at SMPN 1 Marioriwawo in Soppeng district. Second, parents' participation gives significant influence on learning results in soscial sciences subject in class VIII students at SMPN 1 Marioriwawo in Soppeng district. Third, the result of simultaneous test indcates that students' emotional intelligence and parents' participation give significant influence on learning results.

Keywords: students' emotional intelligence, parents' participation, students learning results.

Ini adalah artikel dengan akses terbuka dibawah licenci CC BY-NC-4.0

(https://creativecommons.org/licenses/by-nc/4.0/) 


\section{PENDAHULUAN}

Perkembangan pendidikan dan masyarakat memberi dampak yang signifikan terhadap hasil proses pendidikan. Awal mula pendidikan di mulai dari keluarga sebelum masuk jalur pendidikan formal. Ketika anak didik telah masuk jalur pendidikan formal tidak berarti tanggung jawab pendidikan sepenuhnya berpindah ke tangan guru/pendidik. Peranan orang tua juga sangat menentukan tingkat perkembangan anak dalam menempuh pendidikan. Hal tersebut di amanahkan dalam Undang-undang No. 20 Tahun 2003 tentang Sistem Pendidikan Nasional pasal 1 ayat 1 menyatakan bahwa pendidikan adalah usaha sadar dan terencana untuk mewujudkan suasana belajar dan proses pembelajaran agar peserta didik aktif mengembangkan potensi dirinya untuk memiliki kekuatan spiritual keagamaan, pengendalian diri, kepribadian, kecerdasan, akhlak mulia, serta keterampilan yang diperlukan dirinya, masyarakat dan Negara dan Pendidikan formal adalah jalur pendidikan yang terstruktur dan berjenjang yang terdiri atas pendidikan dasar, pendidikan menengah, dan pendidikan tinggi.

Untuk memperoleh hasil belajar yang baik dapat dilihat dari sarana dan prasarana pembelajaran, aktivitas guru dan siswa dalam kegiatan pembelajaran dan personal yang terlibat dalam kegiatan pembelajaran baik guru dan siswa.

Maka dari itu, Kecerdasan emosional yang dimiliki siswa sangat berpengaruh terhadap hasil belajar, karena emosi memancing tindakan seseorang terhadap apa yang dihadapinya. Oleh karena itu, pendidikan harus mengembangkan secara seimbang kecerdasan dan aspek kepribadian lainya seperti kecerdasan emosi, jasmani, rasa peduli, serta budi pekerti dan kemandirian.

Selain kecerdasan emosional siswa, partisipasi orang tua sangat diperlukan, karena sekolah merupakan partner atau mitra orang tua dalam mengantarkan cita-cita dan membentuk pribadi peserta didik. Partisipasi orang tua dalam pendidikan Indonesia pada dasarnya bukan merupakan sesuatu yang baru, sebab sebelumnya legitimisi telah secara spesifik diatur dalam peraturan Pemerintah Nomor 39 Tahun 1992 Tentang Peran Serta Masyarakat dalam Pendidikan Nasional.

Pada dasarnya partisipasi orang tua sangat dibutuhkan oleh sekolah dalam rangka membantu dan terlibat dalam meningkatkan proses dan hasil pendidikan sekolah. Tanpa dukungan atau partisipasi orang tua, pendidikan (sekolah) tidak akan dapat hasil dengan maksimal. Namun demikian semuanya juga bergantung pada bagaimana cara sekolah mendekati orang tua agar mau ikut berpartisipasi. Mereka dapat diundang untuk membahas bentuk-bentuk kerjasama dalam meningkatkan proses dan hasil pendidikan sekolah, tukar menukar pendapat untuk mencari solusi peningkatan mutu pendidikan. Apabila partisipasi telah terpelihara dengan baik, maka sekolah tidak akan mengalami kesulitan yang berarti dalam mengembangkan berbagai jenis program, karena orang tua dan sekolah telah merasa memahami dan bertanggung jawab terhadapa keberhasilan siswa.

SMP Negeri 1 Marioriwawo merupakan salah satu sekolah yang secara geografisnya terletak di wilayah Kecematan Marioriwawo Kabupaten Soppeng, sekolah ini merupakan sekolah yang strategis karna terletak di pertengahan kecematan Marioriwawo, merupakan salah satu sekolah yang potensial untuk mengkaji begaimana kecerdasan emosional siswa dan partisipasi orang tua terhadap hasil belajar siswa mata pelajaran IPS. Sekolah ini membina siswa sebanyak 390 orang dengan jumlah 18 kelas.

Berdasarkan hasil wawancara dengan guru IPS kelas VIII, ada beberapa yang menghambat hasil belajar siswa mata pelajaran IPS kelas VIII di SMP Negeri 1 Marioriwawo antara lain: motivasi belajar yang rendah, kebiasaan belajar siswa, sarana-prasarana yang disediakan sekolah, seperti media pembelajaran yang kurang, buku paket yang kurang.

Selanjutnya, hasil wawancara dengan salah satu guru bimbingan konseling (BK) di SMP Negeri 1 Marioriwawo, diketahui bahwa terdapat beberapa pelanggaran yang sering dan pernah dilakukan para siswa kelas VIII antara lain, tidak masuk sekolah tanpa keterangan, datang disekolah tidak tepat waktu, bolos saat jam pelajaran berlangsung, siswa mengambil uang temannya sendiri untuk di pakai jajan.

Pelanggaran-pelanggaran yang dilakukan oleh siswa kelas VIII di SMP Negeri 1 Marioriwawo tersebut mengindikasi adanya ketidakmampuan siswa dalam mengembangkan kecerdasan emosional mereka, terutama aspek pengendalian diri mereka. Siswa yang tidak mampu mengendalikan diri akan sulit untuk 
mematuhi aturan yang diterapkan dalam lingkungan sekolah.

Selain itu, berdasarkan hasil wawancara dengan salah satu guru bimbingan konseling (BK) di SMP Negeri 1 Marioriwawo, partisipasi orang tua disekolah yaitu: meyediakan fasilitas yang sesuai dengan kebutuhan anak dalam belajar, Mendorong dan mendukung kemampuan anak dalam belajar, Mengetahui aktivitas anak dalam mempelajari sesuatu, dan Hadir pada pertemuan guru denganorang tua siswa yang diselenggarakan oleh sekolah.

Berdasarkan penelitian yang dilaksanakan oleh Dewi (2014), Terdapat pengaruh positif dan signifikan Kecerdasan Emosional dan Perhatian Orang Tua secara bersama-sama terhadap Prestasi Belajar Akuntansi Siswa Kelas XI Program Ilmu Sosial SMA Negeri 4 Yogyakarta Tahun Ajaran 2013/2014. Sedangkan menurut Dalil (2014), menyatakan bahwa terbukti secara signifikan, karena hasil Ujian $\mathrm{F}$ secara simultan antara partisipasi orang tua dan motivasi terhadap hasil belajar menunjukkan bahwa $\mathrm{F}_{\text {hitung }}$ lebih besar dari $F$ tabel atau $(5.132>3.179)$. Dengan demikian dapat disimpulkan jika pengujian secara bersama-sama (simultan) partisipasi orang tua dan motivasi belajar akan berpengaruh secara signifikan terdapat hasil belajar siswa.

Mengenai hal inilah, pembahasan tentang kecerdasan emosional siswa dan partisipasi orang tua perlu untuk dibahas dan dikaji secara teori dan praktik sehingga di dapat sebuah ide atau suatu bentuk pemahaman yang sama terhadap apa yang seharusnya dilakukan oleh orang tua dan guru supaya hubungan tersebut berjalan harmonis, dengan judul "Pengaruh Kecerdasan Emosional siswa dan Partisipasi Orang tua Terhadap Hasil Belajar Siswa Mata Pelajaran IPS Kelas VIII Di SMP Negeri 1 Marioriwawo Kabupaten Soppeng".

\section{Hasil Belajar}

Hasil belajar dapat dijelaskan dengan memahami dua kata yang membentuknya, yaitu " hasil " dan " belajar ". pengertian hasil menunjuk pada suatu perolehan akibat dilakukanya suatu aktivitas atau proses yang mengakibatkan berubahnya input secara fungsional. Dalam siklus input-proses-hasil, hasil dapat dengan jelas dibedakan dengan input akibat perubahan oleh proses. Begitu pula dalam kegiatan belajar mengajar, setelah mengalami belajar siswa berubah perilakunya dibanding sebelumnya (Purwanto, 2014: 44).
Menurut Winkel dalam Purwanto (2014: 45) hasil belajar adalah perubahan yang mengakibatkan manusia berubah dalam sikap dan tingkah lakunya. Sedangkan menurut Purwanto (2014: 46-47) hasil belajar merupakan realisasi tercapainya tujuan pendidikan, sehingga hasil belajar yang diukur sangat tergantung kepada tujuan pendidikannya, karena hasil belajar diukur untuk mengetahui ketercapaian tujuan pendidikan melaluiproses belajar mengajar.

Menurut Slameto, (2013: 54-71) faktorfaktor yang mempengaruhi belajar yaitu: Faktor jasmaniah meliputi: faktor kesehatan dan cacat tubuh. Faktor psikologis meliputi: intelegensi, perhatian, minat, bakat, motif, kematangan, serta kesiapan. Faktor kelelahan. Faktor keluarga meliputi: cara orang tua mendidik, relasi antaranggota keluarga, suasana rumah, keadaan ekonomi keluarga, pengertian orang tua, serta latar belakang kebudayaan/tingkat pendidikan orang tua.

Sedangkan menurut Djamarah, (2015: 177-205) faktor-faktor yang mempengaruhi hasil belajar antara lain: Faktor dari luar diri siswa atau faktor lingkungan dan Faktor dari dalam diri siswa yaitu Faktor fisiologis dan Faktor psikologis

Menurut Purwanto (2014: 50-53) berdasarkan teori Taksonomi Bloom hasil belajar dalam belajar mengajar dicapai melalui tiga kategori ranah antara lain kognitif, afektif, psikomotor.

\section{Kecerdasan Emosional}

Menurut Satiadarma dan Waruwu, (2013: 26) kecerdasan adalah potensi yang dimiliki seseorang untuk beradaptasi dengan lingkungannya. Purwanto (2006: 52) mengemukakan "Inteligensi adalah kemampuan yang dibawa sejak lahir yang memungkinkan seseorang berbuat sesuatu dengan cara yang tertentu“. Pengertian tersebut menjelaskan bahwa inteligensi merupakan suatu kemampuan seseorang dalam bertindak atau berbuat sesuatu menurut caranya masing-masing, kemampuan seseorang ini tentunya berbeda satu sama lain.

Stein \& Book dalam Hamzah (2012: 69) kecerdasan emosional adalah kemampuan untuk mengenali perasaan, merai dan membangkitkan perasaan untuk membantu pikiran, memahami perasaan dana maknanya, dan mengendalikan perasaan secara mendalam sehingga membantu perkembangan emosi dan intelektual.

Selanjutnya Goleman (2016: 46) juga menyatakan bahwa Kecerdasan Emosional 
adalah orang dengan keterampilan emosional berkembang baik kemungkinan besar akan bahagia dan berhasil dalam kehidupan mereka.

Dari definisi diatas dapat disimpulkan bahwa kecerdasan emosional adalah kecerdasan yang mengenali diri sendiri maupun orang lain, makhluk lain dan lingkungan sekitar. Dalam hal ini emosi mengacu pada perasaan bagaimana mengelolah terhadap informasi akan suatu hubungan.

Menurut Goleman (2016: 43) bahwa ciri-ciri kecerdasan emosional adalah sebagai berikut : Kemampuan memotivasi diri sendiri; Ketahanan menghadapi frustasi; Kemampuan mengendalikan dorongan hati dan tidak melebih-lebihkan kesenangan; Kemampuan menjaga suasana hati dan menjaga agar beban stress tidak melumpuhkan kemampuan berpikir, berempati dan berdoa.

Goleman dalam Iskandar (2012: 60-61) ada lima domain kecerdasan pribadi dalam bentuk kecerdasan emosional, yaitu: Kemampuan mengenali emosi diri, Kemampuan mengelolah emosi, Kemampuan memotivasi diri, Kemampuan mengenali emosi orang lain (Empati), dan Kemampuan membina hubungan sosial.

\section{Partisipasi Orang Tua}

Partisipasi merupakan keterlibatan mental dan emosi dari seseorang di dalam situasi kelompok yang mendorong mereka untuk menyokong kepada pencapaian tujuan pada tujuan kelompok tersebut dan ikut bertanggung jawab terhadap kelompoknya (Dwiningrum, 2011: 50).

Selanjutnya, Slameto (2009: 24) mengatakan bahwa partisipasi orang tua adalah keterlibatan aktif dari seseorang, atau sekelompok orang secara sadar untuk berkontribusi secara sukarela dalam program pengembangan sekolah dan terlibat mulai dari perencanaan, pelaksanaan, monitoring sampai pada tahap evaluasi. Orang tua berperan penting dalam perkembangan anaknya.

Dari pengertian diatas dapat disimpulkan bahwa partisipasi orang tua adalah keterlibatan orang tua untuk mewujudkan tanggung jawab dalam membimbing dan mengarahkan anaknya agar belajar dengan baik.

Menurut Ahmad (2015: 85-88) menyebutkan bahwa partisipasi orang tua dalam pendidikan adalah Mengawasi/Membimbing Kebiasaan Anak Belajar di Rumah, Membimbing dan Mendukung Kegiatan Akademik Anak, Memberikan Dorongan untuk
Meneliti, Berdiskusi tentang Gagasan dan atau Kejadian-kejadian Aktual, Mengarahkan Aspirasi dan Harapan Akademik Anak

\section{Metode Penelitian}

Jenis penelitian ini adalah penelitian kuantitatif. Dalam penelitian yang menjadi variabel bebas adalah kecerdasan emosional siswa $\left(X_{1}\right)$, dan Partisipasi orang tua $\left(X_{2}\right)$, sedangkan variabel terikat hasil belajar siswa (Y).

Definisi operasional dalam penelitian ini adalah Kecerdasan Emosional siswa yang dimaksudkan pada penelitian ini adalah kemampuan emosi siswa dalam mengatur dan menegndalikan suasana perasannya, mengenali perasaan orang lain dan mengekspresikan emosi secara efektif sehingga mampu mengatasi tuntutan.

Partisipasi orang tua yang dimaksud dalam penelitian adalah ikut memperhatikan dan bertanggung jawab atas peserta didik. Tanpa dukungan atau partisipasi orang tua, sekolah tidak akan dapat hasil dengan maksimal.

Hasil belajar siswa yang dimaksudkan dalam penelitian ini adalah hasil yang dicapai oleh siswa setelah melalui proses belajar.

Dalam pengukuran variabel penelitian ini, maka digunakan instrument berupa angket yang diajukan kepada responden dengan menggunakan skala likert. Data yang dihimpun adalah data dari jawaban daftar pertanyaan.

Populasi dalam penelitian ini adalah seluruh siswa kelas VIII SMP Negeri 1 Marioriwawo dengan jumlah 123 siswa.

Adapun teknik pengambilan sampel dalam penelitian ini adalah Cluster random sampling dengan jumlah 90 siswa.

Untuk memperoleh data yang dibutuhkan dalam penelitian ini peneliti menggunakan beberapa teknik pengumpulan data sebagai berikut, Observasi, Angket, Tes, Dokumentasi.

Dalam penelitian ini di gunakan teknik analisis data yang digunakan dalam penelitian ini adalah teknik analisis statistik deskriptif dan teknik analisis statistik inferensial yang bertujuan untuk mengkaji variabel penelitian.

\section{HASIL DAN PENELITIAN}

Untuk memperoleh gambaran kecerdasan emosional siswa, partisipasi orang tua, dan hasil belajar maka setiap variabel dibuatkan tabel frekuensi dan kategori dimana setiap variabel diukur dengan menggunakan 
kategori sangat baik, baik, cukup baik, kurang baik, dan tidak baik.

Berdasarkan olahan data SPSS bahwa gambaran kecerdasan emosional siswa di SMP Negeri 1 Marioriwawo Kabupaten Soppeng, jika ditinjau dari nilai rata-rata maka kecerdasan emosional siswa berada pada kategori baik dengan interval 68-83 dengan frekuensi 46 responden atau $51 \%$. Gambaran partisipasi orang tua di SMP Negeri 1 Marioriwawo Kabupaten Soppeng, jika ditinjau dari nilai ratarata maka partisipasi orang tua berada pada kategori baik dengan interval 68-83 dengan frekuensi 58 responden atau 64,4\%. Sedangkan untuk gambaran hasil belajar di SMP Negeri 1 Marioriwawo Kabupaten Soppeng, jika ditinjau dari nilai rata-rata maka hasil belajar berada pada kategori baik dengan interval 80-89 dengan frekuensi 50 responden atau $55,5 \%$.

Uji normalitas variabel diberlakukan dengan uji Kolmogorof-Smirnof satu sample (one sample Kolmogorof-Smirnof test). Karena nilai signifikansinya lebih besar dari 0,05 , maka distribusi data ini berdistribusi normal.

Untuk Uji Multikolinearitas bahwa setiap variabel bebas memiliki nilai tolerance > 0,1 dan nilai $\mathrm{VIF}<10$. Maka dari itu, dapat disimpulkan bahwa tidak terjadi multikolinearitas antar variabel bebas dalam model regresi, sehingga seluruh variabel bebas dapat digunakan dalam penelitian ini.

Uji Heteroskedastisitas menunjukkan bahwa semua variable mempunyai tingkat signifikansi $\geq 0,05$. Hal ini menandakan bahwa tidak terjadi heteroskedastisitas pada semua variable independen. Karena tidak terjadi heteroskedastisitas, jadi dapat disimpulkan bahwa model persamaan regresi dalam penelitian ini merupakan model yang baik dan bersifat Homokedastisitas.

Untuk Analisis Regresi Linear Berganda maka diperoleh persamaan regresi linear berganda dalam penelitian ini yaitu:

$$
Y=32,146+0,344 X_{1}+0,246 X_{2}
$$

Persamaan regresi tersebut dapat diinterpretasikan sebagai berikut:

a) Konstan $=32,146$. Menunjukkan bahwa meskipun variabel kecerdasan emosional siswa $\left(\mathrm{X}_{1}\right)$ dan partisipasi orang tua $\left(\mathrm{X}_{2}\right)$ tidak memiliki pengaruh terhadap variabel terikat atau bernilai tetap, nilai kinerja $(\mathrm{Y})$ sebagai variabel terikat akan tetap sebesar 32,146 . b) Koefisien $X_{1}=0,344$. Menunjukkan bahwa variabel kecerdasan emosional siswa memiliki pengaruh terhadap hasil belajar. Dengan kata lain, apabila variabel kecerdasan emosional siswa meningkat sementara variabel partisipasi orang tua tetap, maka variabel hasil belajar juga akan ikut meningkat.

c) Koefisien $\mathrm{X}_{2}=0,246$. Menunjukkan bahwa variabel partisipasi orang tua memiliki pengaruh terhadap hasil belajar siswa dimana, apabila variabel partispasi orang tua meningkat sedang variabel kecerdasan emosional tetap, maka hasil belajar juga akan meningkat.

Uji F dilakukan untuk melihat pengaruh variabel bebas secara bersama-sama atau simultan terhadap variabel dependen atau terikat. Uji $F$ dilakukam dengan membandingkan $\mathrm{F}_{\text {hitung }}$ dan $\mathrm{F}_{\text {tabel. }}$. Adapun pengujian hipotesisnya yaitu:

$\mathrm{H}_{\mathrm{o}}$ : kecerdasan emosional siswa dan partispasi orang tua secara simultan tidak mempengaruhi hasil belajar siswa.

$\mathrm{H}_{1}$ : kecerdasan emosional siswa dan partispasi orang tua secara simultan mempengaruhi hasil belajar siswa.

Dengan kriteria :

a) Apabila $F_{\text {hitung }}>F_{\text {tabel }}$ dan tingkat signifikansi $<\alpha(0,05)$, maka variabel independen secara simultan berpengaruh terhadap variabel dependen.

b) Apabila $F_{\text {hitung }}<\mathrm{F}_{\text {tabel }}$ dan tingkat signifikansi $>\alpha(0,05)$, maka variabel independen secara simultan tidak berpengaruh terhadap variabel dependen.

Maka dari itu kita dapat peroleh nilai $\mathrm{F}_{\text {hitung }}=26,244>\mathrm{F}_{\text {tabel }}=3,10$ dengan tingkat signifikansi $0,000<0,05$. Hal ini menandakan bahwa $\mathrm{H}_{\mathrm{o}}$ ditolakn dan $\mathrm{H}_{1}$ diterima yang berarti variabel kecerdasan emosional dan partisipasi orang tua secara bersama-sama atau simultan berpengaruh secara signifikan terhadap variabel hasil belajar. Dengan kata lain variabel-variabel kecerdasan emosional siswa $\left(\mathrm{X}_{1}\right)$ dan partisipasi orang tua $\left(\mathrm{X}_{2}\right)$ mampu menjelaskan besarnya variabel dependen yaitu hasil belajar (Y).

Uji $t$ dilakukan untuk mengetahui apakah parsial variabel independen berpengaruh signifikan terhadap variabel terikat. Pengujian dilakukan dengan membandingkan $t_{\text {hitung }}$ dan $t_{\text {tabel, }}$ dengan cara sebagai berikut: 
a) Apabila $t_{\text {hitung }}>t_{\text {tabel }}$ dan tingkat signifikansi $<\alpha(0,05)$, maka variabel independen secara parsial berpengaruh terhadap variabel dependen. Maka $\mathrm{H}_{\mathrm{o}}$ ditolak dan $\mathrm{H}_{1}$ diterima.

b) Apabila $t_{\text {hitung }}<t_{\text {tabel }}$ dan tingkat signifikansi $>\alpha(0,05)$, maka variabel independen secara parsial tidak berpengaruh terhadap variabel dependen. Maka $\mathrm{H}_{\mathrm{o}}$ diterima dan $\mathrm{H}_{1}$ ditolak.

Berdasarkan pengujian hipotesis maka di dapatkan:

1. Kecerdasan emosional siswa $\left(X_{1}\right)$ diperoleh $t_{\text {hitung }}=4,122>t_{\text {tabel }}=1,662$ dan nilai sig. $0,000<0,05$, maka $\mathrm{H}_{\mathrm{o}}$ ditolak dan $\mathrm{H}_{1}$ diterima. Ini berarti kecerdasan emosional siswa $\left(\mathrm{X}_{1}\right)$ secara parsial memiliki pengaruh yang signifikan terhadap hasil belajar $(\mathrm{Y})$.

2. Partisipasi orang tua $\left(\mathrm{X}_{2}\right)$ diperoleh $\mathrm{t}_{\text {hitung }}=$ $3,024>t_{\text {tabel }}=1,662$ dan nilai sig. $0,003<$ 0,05 , maka $\mathrm{H}_{\mathrm{o}}$ ditolak dan $\mathrm{H}_{1}$ diterima. Ini berarti partisipasi orang tua $\left(\mathrm{X}_{2}\right)$ secara parsial memiliki pengaruh yang signifikan terhadap hasil belajar (Y).

Analisis korelasi berganda digunakan untuk mengetahui pengaruh kecerdasan emosional siswa $\left(\mathrm{X}_{1}\right)$ dan partisipasi orang tua $\left(\mathrm{X}_{2}\right)$ terhadap hasil belajar siswa $(\mathrm{Y})$ di SMP Negeri 1Marioriwawo. Dapat di lihat bahwa interpretasi koefisien korelasi (r) adalah sebesar 0,613 maka pengaruh kecerdasan emosional siswa $\left(\mathrm{X}_{1}\right)$ dan partisipasi orang tua $\left(\mathrm{X}_{2}\right)$ terhadap hasil belajar siswa (Y) di SMP Negeri 1 Marioriwawo memiliki kategori tingkat hubungan yang kuat. Selanjutnya, nilai koefisien determinasi $\mathrm{r}^{2}$ ( $\mathrm{r}$ square) adalah sebesar 0,376 atau sebesar $37,6 \%$. Hal tersebut berarti bahwa meningkat atau menurunya hasil belajar siswa $37,6 \%$ merupakan kontribusi kecerdasan emosional siswa $\left(\mathrm{X}_{1}\right)$ dan partisipasi orang tua $\left(\mathrm{X}_{2}\right)$.

Berdasarkan hasil penelitian maka untuk mengetahui bagaimana pengaruh anatar kecerdasan emosional siswa dan partisipasi orang tua terhadap hasil belajar siswa di SMP Negeri 1 Marioriwawo Kabupaten Soppeng, digunakan angket sebagai teknik pengumpulan data untuk variabel $X_{1}$, variabel $X_{2}$ dan variabel Y. Selanjutnya pada bagian ini akan dikemukakan pembahasan yang berfokus pada hasil pengujian hipotesis, yang akan memberikan jawaban atas perumusan masalah penelitian. Pembahasan setiap hasil pengujian hipotesis dijabarkan sebagai berikut:
1. Pengaruh
kecerdasan emosional
siswa terhadap hasil belajar siswa mata

\section{pelajaran IPS kelas VIII di SMP Negeri 1 Marioriwawo Kabupaten Soppeng.}

Hasil penelitian ini di temukan bahwa kecerdasan emosional siswa memiliki pengaruh signifikan terhadap hasil belajar siswa di SMP Negeri 1 Marioriwawo.

Hal tersebut sejalan dengan pendapat Djamarah, (2015: 177-205) mengenai faktor yang mempengaruhi hasil belajar yaitu Faktor psikologis adalah faktor yang berasal dari dalam diri individu yang sedang belajar, seperti minat, kecerdasan, bakat, motivasi, dan kemampuan kognitif.

Siswa yang mampu mengelolah/menguasai kecerdasan emosionalnya akan berhasil, sebaliknya jika siswa tidak mampu mengelolah/menguasai kecerdasan emosinya. Mashar dalam Yulia (2016: 60) menegaskan bahwa berbagai penelitian dalam bidang psikologi anak telah membuktikan bahwa anak-anak yang memiliki kecerdasan emosional yang tinggi adalah anakanak yang bahagia, percaya diri, populer, dan lebih sukses di sekolah. Mereka lebih mampu menguasai gejolak emosi, menjalin hubungan yang manis dengan orang lain, dapat mengelolah stres, dan memiliki kesehatan mental yang baik.

Temuan penelitian ini sejalan dengan hasil Penelitian yang dilakukan oleh Firdaus Daud (2012) tentang Pengaruh Kecerdasan Emosional (EQ) dan Motivasi Belajar terhadap Hasil Belajar Biologi Siswa SMA 3 Negeri Kota Palopo. Hasil penelitian menunjukkan bahwa: Kecerdasan emosional pengaruh yang positif dan signifikan terhadap hasil belajar Biologi.

2. Pengaruh partisipasi orang tua terhadap hasil belajar siswa mata pelajaran IPS kelas VIII di SMP Negeri 1 Marioriwawo Kabupaten Soppeng.

Hasil penelitian ini di temukan bahwa partisipasi orang tua memiliki pengaruh signifikan terhadap hasil belajar siswa di SMP Negeri 1 Marioriwawo. Partisipasi orang tua besar pengarunya terhadap proses anak dan hasil belajar yang akan dicapai.

Hal tersebut sejalan dengan pendapat Slameto (2013: 60) yang mengemukakan bahwa "keluarga adalah lembaga pendidikan yang pertama dan utama, Siswa yang belajar akan menerima pengaruh dari keluarga berupa, seperti cara orang tua mendidik, relasi antara anggota keluarga, susasan rumah tangga dan keadaan ekonomi keluarga".

Temuan penelitian ini sejalan dengan hasil penelitian Muhammad Dalil (2014) tentang 
"Analisis Partisipasi orang tua terhadap motivasi dan hasil belajar siswa SMP Negeri 17 Marusu Kabupaten Maros" yang menunjukkan atau dapat dikatakan bahwa: terbukti secara signifikan, karena hasil Ujian F secara simultan antara partisipasi orang tua dan motivasi terhadap hasil belajar menunjukkan bahwa $\mathrm{F}$ hitung lebih besar dari $\mathrm{F}_{\text {tabel. }}$

3. Pengaruh kecerdasan emosional siswa dan partisipasi orang tua terhadap hasil belajar siswa mata pelajaran IPS kelas VIII di SMP Negeri 1 Marioriwawo Kabupaten Soppeng.

Hasil penelitian ini di temukan bahwa kecerdasan emosional siswa dan partisipasi orang tua memiliki pengaruh signifikan terhadap hasil belajar siswa mata pelajaran IPS kelas VIII di SMP Negeri 1 Marioriwawo Kabupaten Soppeng. Kecerdasan emosional dan partisipasi orang tua yang ada di SMP Negeri 1 Marioriwawo memiliki kategori baik terhdapat hasil belajar siswa. Hal tersebut sejalan dengan pendapat Mashar dalam Yulia (2016: 61) yang mengemukakan bahwa kecerdasan emosi merupakan salah satu poros keberhasilan individu dalam berbagai aspek kehidupan. Kemampuan anak mengembangkan kecerdasan emosinya, berkorelasi positif dengan keberhasilan akademis, sosial, dan kesehatan mentalnya. Anak yang memiliki kecerdasan emosi tinggi identik dengan anak yang bahagia, bermotivasi tinggi, dan mampu bertahan dalam menjalani berbagai kondisi stres yang di hadapi. Sedangkan menurut Slameto (2013: 54) yang mengemukakan bahwa faktor-faktor yang mempengaruhi hasil belajar salah satunya yaitu Faktor keluarga meliputi: cara orang tua mendidik, relasi antara anggota keluarga, suasana rumah, keadaan ekonomi keluarga, pengertian orang tua, serta latar belakang kebudayaan/tingkat pendidikan orang tua.

Berdasarkan hasil penelitian dapat disimpulkan bahwa kecerdasan emosional siswa memiliki kontribusi lebih besar dari pada partispasi orang tua terhadap hasil belajar IPS siswa. Hal tersebut dapat dilihat dari nilai $\mathrm{R}$ Square kecerdasan emosional siswa lebih tinggi dari pada nilai R Square partispasi orang tua.

\section{SIMPULAN DAN SARAN}

Berdasarkan hasil analisis pengujian hipotesis dan pembahasan yang telah dilakukan sebelumnya, maka kesimpulan yang dihasilkan pada penelitian ini adalah sebagai berikut: (1) Kecerdasan emosional siswa berpengaruh positif terhadap hasil belajar siswa mata pelajaran IPS kelas VIII di SMP Negeri 1 Marioriwawo Kabupaten Soppeng; (2) Partisipasi orang tua berpengaruh positif terhadap hasil belajar siswa mata pelajaran IPS kelas VIII di SMP Negeri 1 Marioriwawo Kabupaten Soppeng; (3) Kecerdasan emosional siswa dan partisipasi orang tua berpengaruh positif terhadap hasil belajar siswa mata pelajaran IPS kelas VIII di SMP Negeri 1 Marioriwawo Kabupaten Soppeng.

Berdasarkan kesimpulan yang telah dikemukakan tersebut, maka ada beberapa saran yang perlu peneliti kemukakan sebagai rekomendasi dalam penelitian ini, yaitu: (1) Diharapkan kepada kepala sekolah/guru agar lebih meningkatkan lagi kreativitas dengan hasil belajar IPS pada siswa kelas VIII di SMP Negeri 1 Marioriwawo Kabupaten Soppeng dengan memperhatikan berbagai indikator yang dapat mempengaruhi kreativitas belajar siswa; (2) Diharapkan kepada kepala sekolah/guru lebih meningkatkan keterlibatan dan kerjasama dengan orang tua siswa agar orang tua mengetahui kegiatan-kegiatan sekolah guna meningkatkan hasil belajar siswa. (3) Diharapkan kepada kepala sekolah/guru selalu meningkatkan kemampuannya dalam mengembangkan dan menyampaikan materi, serta dalam mengelola kelas, menciptakan suasana belajar yang nyaman dan aktif sehingga hasil belajar siswa dapat meningkat.

\section{DAFTAR RUJUKAN}

Ahmad. S. 2015. Manajemen Hubungan Sekolah dengan Masyarakat (dalam rangka pemberdayaan Masyarakat). Jakarta: PT. RajaGrafindo Persada.

Dalil. M. 2014. Analisis partisipasi orang tua terdapat motivasi dan hasil belajar siswa SMP Negeri 17 Marusu Kabupaten Maros. Tesis. Makassar: Program Studi pendidikan Geografi. Program Pascasarjana Universitas Negeri Makassar.

Daud, F. 2012. Pengaruh Kecerdasan Emosional (EQ) dan Motivasi Belajar terhadap Hasil Belajar Biologi Siswa SMA 3 Negeri Kota Palopo. Jurnal Pendidikan dan Pembelajaran, Volume: 2 Tahun 2012 Halaman: 243-255. 
Djamarah. S. B. 2015. Psikologi Belajar. Jakarta: Bineka Cipta.

Dwiningrum. S. I. A. 2011. Desentralisasi dan Partisipasi Masyarakat dalam Pendidikan. Yogyakarta: Pustaka Pelajar.

Goleman. D. 2016. Emotional Intelligence. Jakarta: PT. Kompas gramedia.

Hamzah. 2012. Model Pembelajaran. Jakarta: PT. Bumi Aksara.

Iskandar. 2012. Psikologi Pendidikan (sebuah orientasi baru). Jakarta: Referensi.

Purnawati. D. 2014. Pengaruh kecerdasan emosional dan perhatian orang tua terhadap prestasi belajar akuntansi siswa kelas XI program ilmu sosial SMA Negeri 4 Yogyakarta. Tesis. Pendidikan akuntansi. Yogyakarta: Universitas Negeri Yogyakarta.

Purwanto. 2014. Evaluasi hasil belajar. Yogyakarta: Pustaka Pelajar.
Purwanto. N. 2006. Psikologi Pendidikan. Bandung: Remaja Rosdakarya.

Satiadarma. M. P. \& Waruwu. F. E. 2013. Mendidik Kecerdasan. Jakarta: Pustaka Populer Obor.

Slameto. 2009. Manajemen Berbasis Sekolah. Jakarta: Departemen Pendidikan Nasional.

Slameto. 2013. Belajar dan factor-faktor yang mempengaruhinya. Jakarta: PT. Rineka Cipta.

Undang-undang Republik Indonesia No. 20 Tahun 2003 Tentang Pendidikan Nasional.

Yulia. A. 2016. Pengaruh motivasi belajar, kecerdasan emosional dan lingkungan keluarga terhadap hasil belajar pada mata pelajaran pengantar ekonomi dan bisnis siswa kelas $\mathrm{X}$ smk ardjuna 02 arjosari. Malang: Program Studi Pendidikan Ekonomi FE UM. Jurnal. Volume: 9 Tahun 2016 Halaman: 22. 